\title{
PELAKSANAAN PENDIDIKAN KARAKTER DI SMK NEGERI 4 MAKASSAR
}

\author{
Muh. Rusdi \\ Moh. Natsir Mahmud \\ Muh. Sain Hanafy \\ Muhammad Yaumi
}

Kantor Wilayah Kementerian Agama Provinsi Sulawesi Selatan

Email: muh.rusdiumar@yahoo.co.id

\begin{abstract}
Abstrak: Tulisan ini akan membahas tentang pelaksanaan pendidikan karakter dan resolusi untuk peningkatannya di SMK Negeri 4 Makassar. Penelitian ini merupakan penelitian kualitatif deskriptif. Pendekatan yang digunakan dalam penelitian ini adalah pendekatan multi disipliner (berkaitan dengan berbagai disiplin ilmu pengetahuan), yaitu: pendekatan yuridis normatif, pedagogis, psikologis dan sosiologis. Sumber data primer adalah a). Guru Pendidikan Agama Islam, b). Peserta didik, dan c). Pengurus organisasi Remaja Pencinta Mesjid (RPM), sedangkan data sekunder, yaitu data yang berupa catatan atau dokumen-dokumen yang terkait dengan fokus penelitian yang diarsipkan oleh pihak sekolah. Pengumpulan data dilakukan melalui 1). Observasi (observation); 2). Wawancara mendalam (indepth interview); 3). Studi dokumentasi; dan 4). Focus Group Discussion (FGD) yang terbagi kedalam 2 (dua) sesi, yakni: 1) FGD siswa; dan, 2) FGD manajemen sekolah. Analisis data dilakukan berdasarkan model interaktif dari Miles dan Hubermann. Langkah-langkah analisis data yang dilakukan yaitu: 1). Reduksi data; 2). Penyajian data; dan 3). Verifikasi dan penarikan kesimpulan. Untuk mengecek keabsahan data dalam penelitian ini menggunakan kredibilitas. Adapun teknik yang dilakukan antara lain: 1). Pengamatan secara seksama yang dilakukan secara terus menerus; 2). Triangulasi; dan 3). Melakukan membercheck.

Hasil penelitian menunjukkan bahwa pelaksanan pendidikan karakter di SMK Negeri 4 Makassar, terdiri dari: 1) Pendidikan karakter di setiap mata pelajaran yang dilakukan oleh setiap guru sebelum memulai materi mata pelajaran dengan durasi sekitar 5 (lima) menit; 2) Menjadikan pembentukan karakter sebagai salah satu target capaian pembelajaran yang diposisikan sebagai penopang kompetensi kerja, yakni pengetahuan dan keterampilan kerja yang menjadi kecirian dari SMK Negeri 4 Makassar sebagai sekolah kejuruan; 3) Menjadikan penilaian sikap sebagai syarat mutlak bagi siswa untuk naik kelas; 4) Membangun budaya berkarakter dalam lingkungan sekolah, yang diwujudkan melalui program 3S (Senyum, Salam dan Sapa) dan budaya lingkungan bersih; dan, 5) Mewajibkan siswa untuk mengikuti kegiatan pramuka, yang diakui secara nasional sebagai kegiatan yang ekstrakurikuler yang bermuatan pendidikan karakter.
\end{abstract}

Keywords: Pendidikan Karakter, SMK Negeri 4 Makassar

\section{PENDAHULUAN}

Pemerintah Indonesia, melalui Kementerian Pendidikan Nasional sudah mencanangkan penerapan pendidikan karakter untuk semua tingkat pendidikan, mulai 
SD sampai Perguruan Tinggi. Menurut Muhammad Nuh, pembentukan karakter perlu dilakukan sejak usia dini. Jika karakter sudah terbentuk sejak usia dini, maka tidak akan mudah untuk mengubah karakter seseorang. Ia juga berharap, pendidikan karakter dapat membangun kepribadian bangsa. Mendiknas mengungkapkan hal ini saat berbicara pada pertemuan Pimpinan Pascasarjana LPTK Lembaga Pendidikan Tenaga Kependidikan (LPTK) se-Indonesia di Auditorium Universitas Negeri Medan (Unimed). ${ }^{1}$

Hal ini sejalan dengan Undang-Undang RI nomor 20 tahun 2003 tentang Sistem Pendidikan Nasional pada Pasal 3 yang berbunyi:

"Pendidikan nasional berfungsi mengembangkan kemampuan dan membentuk watak serta peradaban bangsa yang bermartabat dalam rangka mencerdaskan kehidupan bangsa, bertujuan untuk berkembangnya potensi peserta didik agar menjadi manusia yang beriman dan bertakwa kepada Tuhan Yang Maha Esa, berakhlak mulia, sehat, berilmu, cakap, kreatif, mandiri, dan menjadi warga negara yang demokratis serta bertanggung jawab"

Pembangunan karakter merupakan upaya perwujudan amanat Pancasila dan Pembukaan UUD RI 1945 yang dilatar belakangi oleh realitas permasalahan kebangsaan saat ini, seperti: disorientasi dan belum dihayatinya nilai-nilai Pancasila dengan baik dan benar, keterbatasan perangkat kebijakan terpadu dalam mewujudkan nilai-nilai Pancasila, bergesernya nilai etika dalam kehidupan berbangsa dan bernegara, memudarnya kesadaran terhadap nilai-nilai budaya bangsa, ancaman disintegrasi bangsa, dan melemahnya kemandirian bangsa.

Munculnya persoalan sosial dalam kehidupan berbangsa, dan persoalanpersoalan tersebut, tercermin dengan semakin maraknya korupsi yang merambah pada semua sektor kehidupan masyarakat, kesenjangan sosial-ekonomi-politik yang semakin membesar, kerusakan lingkungan yang terjadi di seluruh pelosok negeri ini, masih terjadinya ketidakadilan hukum, pergaulan bebas dan pornografi/sex bebas yang terjadi di kalangan remaja, pemerkosaan di tempat umum atau sarana publik, kekerasan dan kerusuhan (tindakan anarkis, konflik sosial dan kekerasan atas nama agama/sara), serta penuturan bahasa yang buruk telah terjadi dekadensi moral, dan yang lebih fatal lagi merosotnya moralitas, menyebabkan memudarnya karakter anak bangsa ${ }^{3}$.

Untuk mendukung perwujudan cita-cita pembangunan karakter sebagaimana diamanatkan dalam Pancasila dan Pembukaan UUD RI 1945 serta mengatasi permasalahan kebangsaan tersebut di atas, maka Pemerintah menjadikan pembangunan karakter sebagai salah satu kegiatan prioritas pembangunan nasional.

Semangat itu secara implisit ditegaskan dalam Rencana Pembangunan Jangka Panjang Nasional (RPJPN) Tahun 2005- 2025, dimana pendidikan karakter ditempatkan sebagai landasan untuk mewujudkan visi pembangunan nasional, yaitu "mewujudkan masyarakat berakhlak mulia, bermoral, beretika, berbudaya, dan beradab

\footnotetext{
${ }^{1}$ Adian Husaini, Pendidikan Islam Membentuk Manusia Berkarakter dan Beradab (Cet. I; Jakarta: Cakrawala Publishing, 2010), h. 24.

${ }^{2}$ Undang-Undang RI Nomor 20 Tahun 2003, Sistem Pendidikan Nasional (Cet. II; Jakarta: Sinar Grafika, 2012), h. 7.

${ }^{3}$ Cholisin, Konsolidasi Demokrasi Melalui Pengembangan Karakter Kewarganegaraan, Jurnal Civics, Vol. 1, No. 1, Juni, pp. 14-28, 2004, h. 41.
} 
berdasarkan falsafah Pancasila. ${ }^{4}$ Atas dasar itu, pendidikan karakter bukan sekadar mengajarkan mana yang benar dan mana yang salah, lebih dari itu, pendidikan karakter menanamkan kebiasaan (habituation) tentang hal mana yang baik sehingga peserta didik menjadi paham (kognitif) tentang mana yang benar dan salah, mampu merasakan (afektif) nilai yang baik dan biasa melakukannya (psikomotor). Dengan kata lain, pendidikan karakter yang baik harus melibatkan bukan saja aspek "pengetahuan yang baik (moral knowing), akan tetapi juga "merasakan dengan baik atau loving good (moral feeling), dan perilaku yang baik (moral action). Pendidikan karakter menekankan pada habit atau kebiasaan yang terus menerus dipraktikkan dan dilakukan. Oleh karena itu, rumusan tujuan pendidikan nasional tersebut harus menjadi dasar pengembangan pendidikan budaya dan pendidikan karakter bangsa melalui berbagai jalur serta jenjang pendidikan.

Sekalipun, pendidikan karakter telah lama dianut bersama secara tersirat pada penyelenggaraan pendidikan nasional, tetapi rasanya tidak mudah untuk memberi batasan akurat tentang apa sebenarnya yang dimaksud dengan pendidikan karakter itu. Padahal unsur-unsurnya telah dirumuskan dalam tujuan pendidikan nasional sejak Indonesia merdeka hingga sampai sekarang ini. ${ }^{5}$

Sesuai dengan lampiran pada Peraturan Menteri Pendidikan dan Kebudayaan Republik Indonesia Nomor 49 Tahun 2014 tentang Standar Nasional Pendidikan Tinggi, bahwa karakter yang dibentuk dalam pendidikan, berupa sikap atau (attitude). Perlu diingat bahwa keberhasilan pendidikan, bertujuan untuk membentuk pembelajar memiliki kemampuan berupa skill, knowledge dan attitude yang ditampilkan dalam performance yang dibentuk melalui proses pembelajaran yang mencakup cognitive, affective, psychomotoric.

Rumusan sikap, yang tertuang pada lampiran tersebut, bahwa setiap lulusan program pendidikan akademik, vokasi, dan profesi harus memiliki sikap sebagai berikut: 1) Bertakwa kepada Tuhan Yang Maha Esa dan mampu menunjukkan sikap religius; 2) Menjunjung tinggi nilai kemanusiaan dalam menjalankan tugas berdasarkan agama, moral, dan etika; 3) Berkontribusi dalam peningkatan mutu kehidupan bermasyarakat, berbangsa, bernegara dan kemajuan peradaban berdasarkan Pancasila; 4) Berperan sebagai warga negara yang bangga dan cinta tanah air, memiliki nasionalisme dan rasa tanggungjawab pada negara serta bangsa; 5) Menghargai keanekaragaman budaya, pandangan, agama, dan kepercayaan, serta pendapat atau temuan orisinal orang lain; 6) Bekerja sama dan memiliki kepekaan sosial serta kepedulian terhadap masyarakat dan lingkungan; 7) Taat hukum dan disiplin dalam kehidupan bermasyarakat dan bernegara; 8) Menginternalisasi nilai, norma dan etika akademik; 9) Menunjukkan sikap bertanggungjawab atas pekerjaan di bidang keahliannya secara mandiri; dan, 10) Menginternalisasi semangat kemandirian, kejuangan, dan kewirausahaan. ${ }^{6}$

\footnotetext{
${ }^{4}$ Direktorat Jenderal Pendidikan Anak Usia Dini Nonformal dan Informal. Petunjuk Teknis Pengajuan, Penyaluran dan Pengelolaan Bantuan Pendidikan Karakter Melalui Satuan Pendidikan Nonformal, (Jakarta: 2013), h. 1-2.

${ }^{5}$ Muhammad Yaumi, Makalah Seminar Pendidikan Karakter Bangsa: Peran Guru, Teori dan Implementasi (Bekasi: Yayasan Pendidikan Ar-Rahman, 2012), h. 2.

${ }^{6}$ Tim Kurikulum dan Pembelajaran Direktorat Pembelajaran dan Kemahapeserta didikan. Kurikulum Pendidikan Tinggi (Jakarta: Direktorat Jenderal Pendidikan Tinggi Kementerian Pendidikan dan Kebudayaan, 2014), h. 81.
} 
Masalah kemerosotan nilai, moral dan akhlak telah menjadi salah satu problematika kehidupan bangsa Indonesia terpenting di abad ke-21 ini. Merosotnya nilai-nilai moral yang mulai melanda masyarakat kita saat ini tidak lepas atas ketidakefektifan penanaman nilai-nilai moral, baik di lingkungan keluarga, sekolah dan masyarakat secara keseluruhan. Anak dilahirkan dengan fitrah tauhid yang murni, Allah swt. menciptakan manusia dengan naluri beragama yaitu agama tauhid. Kalau ada manusia tidak beragama tauhid, maka hal itu tidaklah wajar. Mereka tidak beragama tauhid itu hanyalah lantaran pengaruh lingkungan, Allah swt. menerangkan dalam QS. al-Rum/30:30

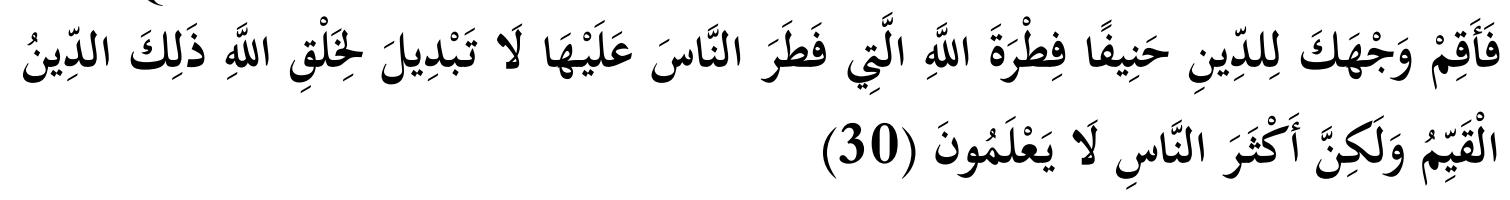

Terjemahnya:

Maka hadapkanlah wajahmu dengan lurus kepada agama Allah; (tetaplah atas) fitrah Allah yang telah menciptakan manusia menurut fitrah itu. tidak ada peubahan pada fitrah Allah. (Itulah) agama yang lurus; tetapi kebanyakan manusia tidak mengetahui.

Sehubungan dengan ayat tersebut di atas, ada dua faktor utama yang dapat membuat anak tumbuh dalam iman yang hak, berhiaskan diri dengan etika Islam, dan sampai pada puncak keutamaan spiritual dan kemuliaan personal. Dua faktor tersebut adalah pendidikan Islam yang utama dan pendidikan lingkungan yang baik. Jika dua faktor tersebut terpenuhi, maka anak akan tumbuh dan berkembang dengan keutamaan-keutamaan budi pekerti, spiritual dan etika agama yang lurus.

Melalui teladan yang baik (uswah hasanah), merupakan pendukung terbentuknya akhlak yang mulia. Ini akan lebih mengena melalui orang-orang terdekat seperti orang tua, guru, dan lainnya, yang mempunyai peran penting di dalam kesehariannya. Kecenderungan manusia meniru belajar lewat peniruan, menyebabkan keteladanan menjadi sangat penting artinya dalam proses belajar mengajar. Sebagaimana firman Allah swt. dalam QS. al-Ahzāb/33:21:

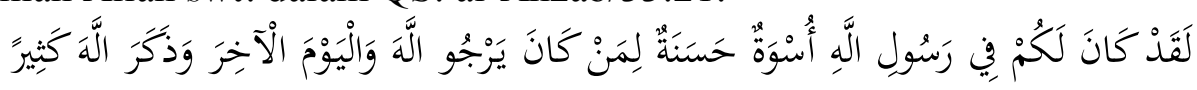

Terjemahan:

Sesungguhnya Telah ada pada (diri) Rasulullah itu suri teladan yang baik bagimu (yaitu) bagi orang yang mengharap (rahmat) Allah dan (kedatangan) hari kiamat dan dia banyak menyebut Allah.

Lingkungan yang baik mendukung terbentuknya karakter yang baik, begitu pula sebaliknya di lingkungan yang buruk menjadi hambatan besar dalam pembentukan karakter anak. Pada dasarnya setiap muslim wajib melaksanakan sikap berbuat jujur, baik antar sesama muslim dengan muslim, maupun antar muslim dan non muslim. Demikian pula berbuat toleran, menepati janji, sportif, kerjasama, pemurah dan lain sebagainya. Oleh karena itu, menjadi hal yang prisip pada dunia pendidikan untuk mengintegrasikan nilai-nilai tersebut utamanya pada mata peserta didikan pendidikan agama dan kegiatan-kegiatan Rohani Islam, sehingga mampu menciptakan lingkungan yang kondusif sebagai faktor penunjang keberhasilan pendidikan karakter.

Pada kenyataannya pendidikan agama pada saat ini lebih dikesampingkan dibandingkan dengan pengaruh lingkungannya, yang terkadang cenderung lebih banyak 
ke arah negatif. Dampaknya dapat mempengaruhi sikap dan perilakunya untuk beribadah semakin menurun. Apalagi dikalangan remaja SMA, yang dapat dikatakan masa mencari jati diri, sehingga mudah terpengaruh oleh lingkungan sekitar yang dapat berdampak pada keseharian baik dari segi moral hingga pada ketaatannya dalam menjalankan ibadah. Pada kenyataannya diusia remaja Sekolah Menengah Atas, atau Sekolah Menengah Kejuruan sudah dijatuhi hukuman apabila tidak menjalankan ibadah karena sudah masuk umur (baligh).

Tulisan ini akan membahas tentang pelaksanaan pendidikan karakter dan resolusi untuk peningkatannya di SMK Negeri 4 Makassar.

\section{KAJIAN TEORETIK}

\section{Pengertian Pendidikan Karakter}

Karakter dapat didefinisikan sebagai paduan dari pada segala tabiat manusia yang bersifat tetap, sehingga menjadi tanda yang khusus untuk membedakan orang yang satu dengan yang lainnya. Karakter merupakan siapa anda sesungguhnya. Batasan ini menunjukkan bahwa karakter sebagai identitas yang dimiliki seseorang yang bersifat menetap sehingga seseorang atau sesuatu itu berbeda dari yang lain. ${ }^{7}$ Karakter adalah cara berpikir dan berperilaku yang menjadi ciri khas setiap individu untuk hidup dan bekerjasama, baik dalam lingkup keluarga, masyarakat, bangsa dan negara. Individu yang berkarakter baik adalah individu yang mampu membuat keputusan dan siap mempertanggungjawabkannya. ${ }^{8}$

Karakter seseorang berkembang berdasarkan potensi yang dibawa sejak lahir atau yang dikenal sebagai karakter dasar yang bersifat biologis. Aktualisasi karakter dalam bentuk perilaku sebagai hasil perpaduan antara karakter biologis dan hasil hubungan atau interaksi dengan lingkungannya. Karakter dapat dibentuk melalui pendidikan, karena pendidikan merupakan alat yang paling efektif untuk menyadarkan individu dalam jati diri kemanusiaannya. Dengan pendidikan akan dihasilkan kualitas manusia yang memiliki kehalusan budi dan jiwa, memiliki kecemerlangan pikir, kecekatan raga, dan memiliki kesadaran penciptaan dirinya. Pendidikan memberikan dampak yang lebih kuat dalam membentuk kualitas manusia. ${ }^{9}$

Karakter adalah kulminasi dari kebiasaan yang dihasilkan dari pilihan etik, perilaku dan sikap, yang dimiliki individu yang merupakan moral yang prima walaupun ketika tidak seorang pun yang melihatnya. Karakter mencakup keinginan sesorang untuk melakukan yang terbaik, kepedulian terhadap kesejahteraan orang lain, kognisi dari pemikiran kritis dan alasan moral, dan pengembangan keterampilan interpersonal dan emosional yang menyebabkan kemampuan individu untuk bekerja secara efektif

${ }^{7}$ Anita Yus, “Pengembangan Karakter Melalui Hubungan Anak-Kakek-Nenek”, dalam Arismantoro, Tinjauan Berbagai Aspek Character Building (Tiara Wacana: Yogyakarta, 2008), h. 91.

${ }^{8}$ Ahmad Muhaimin Azzel, Urgensi Pendidikan Karakter di Indonesia; Revitalisasi Pendidikan Karakter terhadap Keberhasilan Belajar dan Kemajuan Bangsa (Yogyakarta: ar-Ruzz Media, 2011), h. 28.

${ }^{9}$ Wahid Munawar, "Peengembangan Model Pendidikan Afeksi Berorientasi Konsiderasi untuk Membangun Karakter Siswa yang Humanis di Sekolah Menengah Kejuruan”, Makalah dalam Procedings of The $4^{\text {th }}$ International Conference on Teacher Education; Join Conference UPI \& UPSI (Bandung: UPI, 8-10 November 2010), h. 339. 
dengan orang lain dalam situasi setiap saat. ${ }^{10}$ Adapun perilaku atau akhlak,didefinisikan oleh Imam al-Ghazali, yakni ungkapan tentang keadaan yang melekat pada jiwa dan darinya timbul perbuatan-perbuatan dengan mudah tanpa membutuhkan kepada pemikiran dan pertimbangan. ${ }^{11}$

Pendidikan karakter adalah sebuah sistem yang menanamkan nilai-nilai karakter pada peserta didik yang mengandung komponen pengetahuan, kesadaran individu, tekad serta adanya kemauan dan tindakan untuk melaksanakan nilai-nilai, baik terhadap Tuhan Yang Maha Esa, diri sendiri, sesama manusia, lingkungan, maupun bangsa, sehingga akan terwujud Insan Kamil. Sedang pendidikan karakter adalah pendidikan budi pekerti plus yaitu yang melibatkan aspek pengetahuan (cognitive), perasaan (feeling), dan tindakan (action). ${ }^{12}$ Pendidikan karakter yang diterapkan secara sistematis dan berkelanjutan akan membuat peserta didik menjadi cerdas emosinya. Kecerdasan emosi sangat penting dalam mempersiapkan peserta didik menyongsong masa depan, karena akan lebih mudah dan berhasil menghadapi segala macam tantangan kehidupan termasuk tantangan untuk berhasil secara akademis. $^{13}$

Pendidikan karakter memiliki makna lebih tinggi dari pendidikan moral, karena pendidikan karakter tidak hanya berkaitan dengan masalah benar salah, tetapi bagaimana menanamkan kebiasaan tentang hal-hal yang baik dalam kehidupan, sehingga peserta didik memiliki kesadaran dan pemahaman yang tinggi, serta kepedulian dan komitmen untuk menerapkan kebijakan dalam kehidupan sehari-hari. Dengan demikian dapat dikatakan bahwa karakter merupakan sifat alami seseorang dalam merespons situasi secara bermoral, yang diwujudkan dalam tindakan nyata melalui perilaku baik, jujur, bertanggung jawab, hormat terhadap orang lain dan nilainilai karakter mulia lainnya. Dalam konteks pemikiran Islam, karakter berkaitan dengan Iman dan Ikhlas. Hal ini sejalan dengan ungkapan Aristoteles, bahwa karakter erat kaitannya dengan kebiasaan yang terus menerus dipraktikkan dan diamalkan ${ }^{14}$.

Sementara menurut T. Ramli, pendidikan karakter memiliki esensi dan makna yang sama dengan pendidikan moral dan pendidikan akhlak. Tujuannya adalah membentuk pribadi anak, supaya menjadi manusia yang baik, warga masyarakat dan warga negara yang baik. Adapun kriteria manusia yang baik, warga masyarakat yang baik, dan warga negara yang baik bagi suatu masyarakat atau bangsa, secara umumadalah nilai-nilai sosial tertentu, yang banyak dipengaruhi oleh budaya masyarakat dan bangsanya. Oleh karena itu, hakikat dari pendidikan karakter dalam konteks pendidikan di Indonesia adalah pedidikan nilai yakni pendidikan nilai-nilai luhur yang bersumber dari budaya bangsa Indonesia sendiri, dalam rangka membina kepribadian generasi muda.

\footnotetext{
${ }^{10}$ Muhammad Yaumi, Makalah Seminar Pendidikan Karakter Bangsa: Peran Guru, Teori dan Implementasi, h. 3.

${ }^{11}$ Mohammad Nasirudin, Pendidikan Tasawuf, (Semarang: Rasail Group, 2010), h. 32.

${ }^{12}$ Masnur Muslich, Pendidikan Karakter manjawab Tantangan Krisis Multidimensional (Jakarta: Bumi Aksara, 2011), h. 14.

${ }^{13}$ Ahmad Muhaimin Azzel, Urgensi Pendidikan Karakter di Indonesia; Revitalisasi Pendidikan Karakter terhadap Keberhasilan Belajar dan Kemajuan Bangsa, h. 30.

${ }^{14}$ E. Mulyasa, Manajemen Pendidikan Karakter(Cet.IV; Jakarta: Bumi Aksara, 2014), h. 3.
} 
Para pakar pendidikan pada umumnya sependapat tentang pentingnya upaya peningkatan pendidikan karakter pada jalur pendidikan formal. Namun demikian, ada perbedaan-perbedaan pendapat di antara mereka tentang pendekatan dan modus pendidikannya. Berhubungan dengan pendekatan, sebagian pakar menyarankan penggunaan pendekatan-pendekatan pendidikan moral yang dikembangkan di negaranegara barat, seperti: pendekatan perkembangan moral kognitif, pendekatan analisis nilai, dan pendekatan klarifikasi nilai. Sebagian yang lain menyarankan penggunaan pendekatan tradisional, yakni melalui penanaman nilai-nilai sosial tertentu dalam diri peserta didik.

Penerapan pendidikan karakter pada pelaksanaan pembelajaran dilaksanakan dengan menggunakan strategi yang tepat. Strategi yang tepat adalah strategi yang menggunakan pendekatan kontekstual. Alasan penggunaan strategi kontekstual adalah bahwa strategi tersebut dapat mengajak siswa menghubungkan atau mengaitkan materi yang dipelajari dengan dunia nyata. Dengan dapat mengajak menghubungkan materi yang dipelajari dengan dunia nyata, berati siswa diharapkan dapat mencari hubungan antara pengetahuan yang dimilikinya dengan penerapan pengetahuan tersebut dalam kehidupan sehari-hari. Dengan pendekatan itu, siswa lebih memiliki hasil yang komprehensif tidak hanya pada tataran kognitif (olah pikir), tetapi pada tataran afektif (olah hati, rasa, dan karsa), serta psikomotor (olah raga). Adapun beberapa strategi pembelajaran kontekstual antara lain (a) pembelajaran berbasis masalah, (b) pembelajaran kooperatif, (c) pembelajaran berbasis proyek, (d) pembelajaran pelayanan, dan (e) pembelajaran berbasis kerja. Kelima strategi tersebut dapat memberikan nurturant effect pengembangan karakter siswa, seperti: karakter cerdas, berpikir terbuka, tanggung jawab, rasa ingin tahu. ${ }^{15}$

Pendidikan karakter dapat diimplmetasikan melalui beberapa strategi dan pendekatan yang meliputi: (1) pengintegrasian nilai dan etika pada mata pelajaran; (2) internalisasi nilai positif yang di tanamkan oleh semua warga sekolah (kepala sekolah, guru, dan orang tua); (3) pembiasaan dan latihan; (4) pemberian contoh dan teladan; (5) penciptaan suasana berkarakter di sekolah; dan (6) pembudayaan. Sebagai upaya untuk meningkatkan kesesuaian dan mutu pendidikan karakter, Kementerian Pendidikan Nasional mengembangkan Grand Design pendidikan karakter untuk setiap jalur, jenjang, dan jenis satuan pendidikan. Berdasarkan grand design yang di kembangkan Kemendiknas, secara psikologis dan sosial kultural pembentukan karakter dalam diri individu merupakan fungsi dari seluruh potensi individu manusia (kognitif, afektif, konatif, dan psikomotorik) dalam konteks interaksi sosial kultural (dalam keluarga, sekolah, dan masyarakat) dan berlangsung sepanjang hayat Grand design menjadi rujukan konseptual dan operasional pengembangan, pelaksanaan, dan penilaian pada setiap jalur dan jenjang pendidikan. ${ }^{16}$

Berdasarkan grand design yang dikembangkan Kemendiknas (2010), secara psikologis dan sosial kultural pembentukan karakter dalam diri individu merupakan fungsi dari seluruh potensi individu manusia (kognitif, afektif, konatif, dan

${ }^{15}$ Tim Penyusun, Pedoman Pelaksanaan pendidikan Karakter: Berdasarkan Pengalaman di Satuan Pendidikan Rintisan (Jakarta: Puskurbuk Badan Penelitian dan Pengembangan Kementerian Pendidikan Nasional, 2011), h. 8-9.

${ }^{16}$ Tim Penyusun, Pedoman Pelaksanaan pendidikan Karakter: Berdasarkan Pengalaman di Satuan Pendidikan Rintisan, h. 13. 
psikomotorik) dalam konteks interaksi sosial kultural (dalam keluarga, sekolah, dan masyarakat) dan berlangsung sepanjang hayat. Konfigurasi karakter dalam konteks totalitas proses psikologis dan sosial-kultural tersebut dapat dikelompokkan dalam:

a) Olah hati (spiritual and emotional development);

b) Olah pikir (intellectual development);

c) Olahraga dan kinestetik (physical and kinestetic development); dan,

d) Olah rasa dan karsa (affective and creativity development). berikut ${ }^{17}$ :

Pengolompokkan tersebut secara diagramatik dapat digambarkan, sebagai

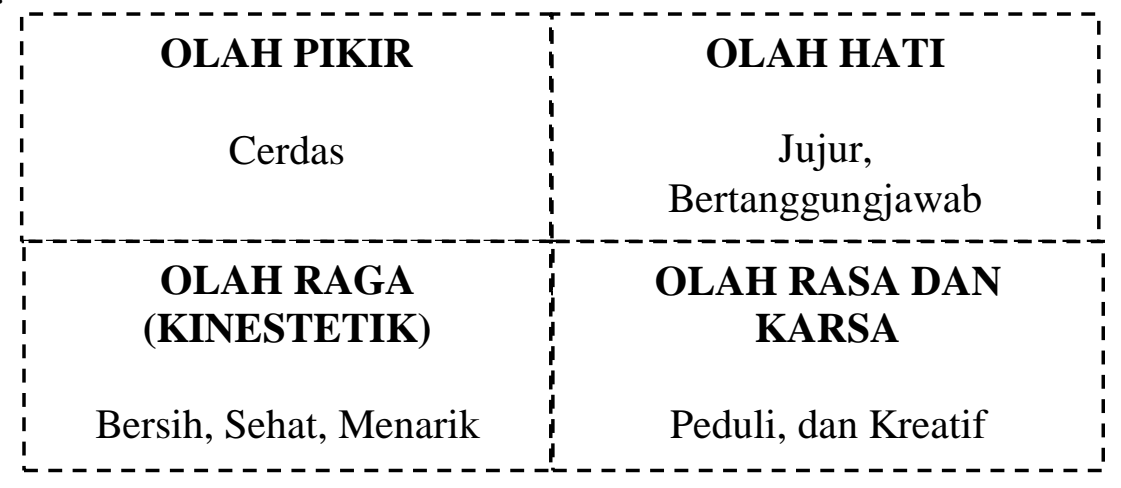

Berdasarkan pembahasan di atas dapat ditegaskan bahwa pendidikan karakter merupakan berbagai upaya yang dirancang dan dilaksanakan secara sistematis untuk menanamkan nilai-nilai perilaku peserta didik yang berhubungan dengan Tuhan Yang Maha Esa, diri sendiri, sesama manusia, lingkungan dankebangsaan, yang terwujud dalam pikiran, sikap, perasaan, perkataan dan perbuatan, berdasarkan norma agama, hukum, tata krama, budaya dan adat istiadat.

Megawati, sebagai pencetus pendidikan karakter di Indonesia, telah menyusun 9 (sembilan) pilar karakter mulia yang selayaknya dijadikan acuan dalam pendidikan karakter, baik di sekolah maupun di luar sekolah, yakni sebagai berikut:

a) Cinta Allah dan kebenaran;

b) Tanggung jawab, disiplin dan mandiri;

c) Amanah;

d) Hormat dan santun;

e) Kasih sayang, peduli dan kerja sama;

f) Percaya diri, kreatif dan pantang menyerah;

g) Adil dan berjiwa kepemimpinan;

h) Baik dan rendah hati; dan,

i) Toleran dan cinta damai. ${ }^{18}$

Dalam perspektif Islam, pendidikan karakter secara teoretik sebenarnya telah ada sejak Islam diturunkan di dunia, seiring diutusnya Nabi Muhammad Saw. untuk memperbaiki atau menyempurnakan akhlak (karakter) manusia. Ajaran Islam sendiri mengandung sistematika ajaran yang tidak hanya menekankan pada aspek keimanan, ibadah dan muamalah tetapi juga akhlak. Pengamalan ajaran Islam secera utuh (kaffah)

${ }^{17}$ Santo Yoseph Denpasar, Pendidikan Karakter Di Pendidikan Dasar Dan Menengah. (Kementerian Pendidikan Nasional Direktorat Jenderal Manajemen Pendidikan Dasar dan Menengah Direktorat Pembinaan Sekolah Mengah Pertama, 2012), h. 3.

${ }^{18}$ E. Mulyasa, Manajemen Pendidikan Karakter, h. 5. 
merupakan model karakter seorang muslim, bahkan dipersonifikasikan dengan model karakter Nabi Muhammad SAW, yang memiliki sifat shiddiq, tabligh, amanah dan fathanah.

Pendidikan karakter bersumber pada Agama, Pancasila, budaya dan tujuan pendidikan nasional. Beberapa muatan pendidikan karakter, yaitu: 1) Religius; 2) Jujur; 3) Toleransi; 4) Disiplin; 5) Kerja keras; 6) Kreatif; 7) Mandiri; 8) Demokratis; 9) Rasa ingin tahu; 10) Semangat kebangsaan; 11) Cinta tanah air; 12) Menghargai prestasi; 13) Bersahabat/komunikatif; 14) Cinta damai; 15) Gemar membaca; 16) Peduli lingkungan; 17) Peduli sosial; dan, 18) Tanggungjawab. ${ }^{19}$

\section{Tujuan Pendidikan Karakter}

Pendidikan karakter bertujuan mengembangkan nilai-nilai yang membentuk karakter bangsa yaitu Pancasila, yang meliputi: ${ }^{20}$

a. Mengembangkan potensi peserta didik agar menjadi manusia berhati baik, berpikiran baik, dan berprilaku baik;

b. Membangun bangsa yang berkarakter Pancasila; dan,

c. Mengembangkan potensi warganegara agar memiliki sikap percaya diri, bangga pada bangsa dan negaranya serta mencintai umat manusia.

Secara umum, tujuan pendidikan dalam al-Qur'an adalah beribadah kepada Allah dalam pengertian yang luas, meliputu masalah-masalah ritual dan sosial, dengan maksud untuk melaksanakan tugas kekhalifahan, yaitu memakmurkan bumi persada di atas hukum-hukum Allah. ${ }^{21}$ berikut:

Tujuan umum di atas dapat dirinci menjadi tujuan-tujuan spesifik, sebagai

a) Menyadarkan manusia sebagai individu akan posisinya di antara makhluk yang lain dan tanggung jawabnya secara pribadi dalam kehidupannya. ${ }^{22}$

b) Menyadarkan manusia akan hubungan dan tanggung jawabnya sebagai makhluk sosial. $^{23}$

c) Menyadarkan manusia akan keberadaan dan pemanfaatan alam dengan berbagai rahasia yang ada di dalamnya untuk digali dan dimanfaatkan bagi kesejahteraan manusia. $^{24}$

d) Menyadarkan manusia akan keberadaan pencipta alam semesta untuk mereka sembah. $^{25}$

Tujuan pendidikan yang ingin dicapai oleh al-Qur'an adalah membina manusia guna mampu menjalankan fungsinya seagai hamba Allah dan khalfah-Nya. Manusia

\footnotetext{
${ }^{19}$ Bambang Q Anees dan Adang Hambali, Pendidikan Karakter Berbasis Al-Qur'an (Jakarta: Simbiosa Rekatama Media, 2010), h. 21.

${ }^{20}$ Kementerian Pendidikan Nasional, Panduan Pelaksanaan Pendidikan Karakter, (Jakarta: 2011), h. 7.

${ }^{21}$ Syahidin, Menelusuri Metode Pendidikan dalam al-Qur'an (Cet. I; Bandung: Alfabeta, Bandung), h. 63.

${ }^{22}$ Lihat QS. Maryam/19: 90-93.

${ }^{23}$ Lihat QS. Ali Imran/3: 110.

${ }^{24}$ Lihat QS. Luqman/31: 10.

${ }^{25}$ Lihat QS. al-An'am/6: 102-103.
} 
yang dibina adalah makhluk yang memiliki unsure-unsur material (jasmani) dan immaterial (akal dan jiwa). Pembinaan akalnya menghasilkan ilmu. Pembinaan jiwanya menghasilkan kesucian dan etika, sedangkan pembinaan jasmaninya menghasilkan keterampilan. Dengan penggabungan unsur-unsur tersebut, terciptalah makhluk dwi dimensi dalam satu keseimbangan, dunia dan akhirat, ilmu dan iman. Itu sebabnya dalam pendidikan Islam dikenal istilah adab ad-din dan adab ad-dunya. ${ }^{26}$

Ajarilah anak-anakmu etika berbicara, mendengar, duduk, meminta izin, makan, tidur, masuk rumah, keluar, buang air, berjalan, dan lain sebagainya yang merupakan etika-etika khusus dan umum. Tanamkanlah di hati mereka akhlak yang mulia dan kebiasaan yang baik, menghormati orang yang lebih tua, melindungi orang yang lebih kecil, mencintai orang-orang yang miskin, membantu orang-orang yang membutuhkan, membantu orang-orang yang saleh, menjauahi hal-hal yang tidak berguna, membenci perilaku zalim, aniaya, keburukan, mengumpat, mencaci maki, gibah, adu domba, saling memanggil dengan sebutan-sebutan buruk, sombong, dusta, kikir, iri, dengki, takabur, uzub, pengangguran dan malas. ${ }^{27}$

Pendidikan karakter bertujuan untuk meningkatkan mutu proses dan hasil pendidikan yang mengarah pada pembentukan karakter dan akhlak mulia peserta didik secara utuh, terpadu dan seimbang, sesuai dengan standar kompotensi lulusan pada setiap satuan pendidikan. Melalui pendidikan karakter peserta didik diharapkan mampu secara mandiri meningkatkan dan menggunakan pengetahuannya, mengkaji dan menginternalisasikan serta mempersonalisasikan nilai-nilai karakter dan akhlak mulia sehingga terwujud dalam perilaku sehari-hari. ${ }^{28}$

Daniel Goleman yang terkenal dalam bukunya Multiple Intelligenceand EmosionalIntelligence, menyebutkan bahwa pendidikan karakter merupakan pendidikan nilai, yang mencakup sembilan nilai dasar yang saling terkait, yaitu:

a) Responsibility (tanggung jawab);

b) Respect (rasa hormat);

c) Fairness (keadilan);

d) Courage (keberanian);

e) Honesty (kejujuran);

f) Citizenship (rasa kebangsaan);

g) Self-discipline (disiplin diri);

h) Caring (peduli); dan,

i) Perseverance (ketekunan)

Dalam pandangan Daniel Goleman, yang dikutip dari buku Pembelajaran NilaiKarakter yang ditulis oleh Sutarjo Adisusilo, dijelaskan bahwa jika pendidikan nilai berhasil menginternalisasikan kesembilan nilai dasar tersebut dalam diri peserta didik, maka akan terbentuk seorang pribadi yang berkarakter, dan pribadi yang berwatak. Lebih lanjut dijelaskan bahwa pendidikan nilai harus dimulai di rumah, dikembangkan di lembaga pendidikan sekolah, dan diterapkan secara nyata dalam masyarakat. ${ }^{29}$

\footnotetext{
${ }^{26}$ M. Quraish Shihab, Membumikan al-Qur'an' Fungsi dan Peran Wahyu dalam Kehidupan Masyarakat (Cet. XXIII; Bandung: Mizan, 2002), h. 106.

${ }^{27}$ Abdul Azizl al-Fauzan, Fiqh at-Ta'amul Ma'a an-Nas. Terj. Iman Firdaus dan Ahmad Solahudin, Fikih Sosial (Cet. I; Jakarta: Qisthi Press, 2007), h. 228.

${ }^{28}$ E. Mulyasa, Manajemen Pendidikan Karakter, h. 9.

${ }^{29}$ Sutarjo Adisusilo, Pembelajaran Nilai Karakter, h. 79-80.
} 
Adapun proses untuk membentuk akhlak peserta didik yang baik dapat dilakukan melalui:

a. Pemahaman (ilmu)

Pemahaman dengan cara menginformasikan tentang hakikat dan nilai-nilai yang terkandung didalamnya, pemahaman yang diberikan setiap saat sehingga dapat dipahami dan diyakini bahwa obyek itu benar-benar berharga dan bernilai. Dengan demikian akan menimbulkan rasa suka atau tertarik di dalam hatinya sehingga peserta didik akan melakukan perbuatan yang baik keseharianya sesuai dengan apa yang ia pahami dan yakini. ${ }^{30}$

b. Pembiasaan (amal)

Pembiasaan dilakukan guna menguatkan obyek yang telah dipahami dan diyakini, sehingga dapat menjadi suatu bagian yang terikat pada dirinya. Kemudian menjadi suatu kebiasaan perbuatan atau akhlak. Sebagai contoh dengan membiasakan diri untuk melaksanakan ibadah shalat berjamaah di masjid. Ketika tidak melaksanakan shalat berjamaah di masjid akan menimbulkan rasa yang kurang, seakan ada hal berharga yang hilang.

c. Melalui teladan yang baik (uswah hasanah)

Uswatun hasanah merupakan pendukung terbentuknya akhlak yang mulia. Ini akan lebih mengena melalui orang-orang terdekat, seperti orang tua, guru dan lainnya, yang mempunyai peran penting di dalam kesehariannya. Kecenderungan manusia belajar lewat peniruan, menyebabkan keteladanan menjadi sangat penting artinya dalam proses belajar mengajar. Sebagamana Firman Allah swt. dalam QS. Al-Ahzāb 21:

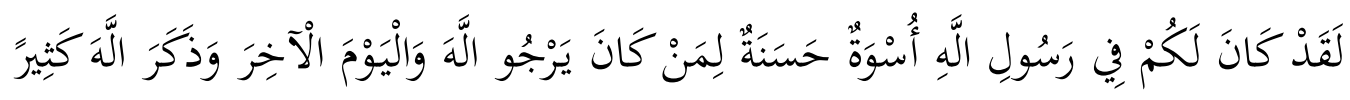

Terjemahanya:

Sesungguhnya Telah ada pada (diri) Rasulullah itu suri teladan yang baik bagimu (yaitu) bagi orang yang mengharap (rahmat) Allah dan (kedatangan) hari kiamat dan dia banyak menyebut Allah. (QS. AlAhzāb/33: 21).

\section{Prinsip-Prinsip Pendidikan Karakter}

Tidak ada petunjuk teknis yang paling efektif untuk dilakukan dalam menunjang keberhasilan pelaksanaan pendidikan karakter. Tidak terdapat juga strategi pelaksanaan yang bisa berlaku umum yang sesuai dengan seluruh kondisi lingkungan sekolah. Analisis kebutuhan merupakan cara yang baik untuk dilakukan sebelum lebih jauh mengimplementasikan pendidikan karakter.

Namun, secara teoretis terdapat beberapa prinsip yang dapat digeneralisasi untuk mengukur tingkat keberhasian suatu pelaksanaan pendidikan karakter. Lickona, Schaps dan Lewis dalam CEP's Eleven Principles of Effective Character Education, menguraikan 11 (sebelas) prinsip dasar dalam menunjang keberhasilan pelaksanaan pendidikan karakter. 11 (sebelas) prinsip yang dimaksud adalah: ${ }^{31}$

\footnotetext{
${ }^{30}$ Mohammad Nasirudin, Pendidikan Tasawuf, h. 36-37.

${ }^{31}$ Muhammad Yaumi. Makalah Seminar Pendidikan Karakter Bangsa: Peran Guru, Teori dan Implementasi, h. 4.
} 
a) Komunitas sekolah mengembangkan nilai-nilai etika dan kemampuan inti sebagai landasan karakter yang baik

Komunitas sekolah yang dimaksud terdiri atas kepala sekolah, staf administrasi, staf pengajar dan berbagai komponen lain, yangmemiliki hubungan langsung dengan sekolah. Komunitas tersebut secara bersama-sama mengembangkan nilai-nilai inti etika seperti kepedulian, kejujuran, keadilan, pertanggungjawaban, serta penghargaan pada diri sendiri dan orang lain. Di samping itu, mereka juga mengembangkan nilai-nilai kinerja (kemampuan), yang mencakup ketekunan, upaya terbaik, kegigihan, pikiran kritis, dan sikap-sikap positif.

b) Sekolah mendefinisikan karakter secara komprehensif untuk memasukkan pemikiran, perasaan, dan perbuatan

Mendefinisikan karakter secara mendalam merupakan tugas yang perlu dilakukan sekolah dalam membangun karakter peserta didik. Karakter yang baik mencakup pemahaman, kepedulian dan tindakan atas dasar nilai-nilai inti etika dan nilai-nilai kinerja. Pemahaman yang mendalam tentang nilai-nilai inti etika dan nilai-nilai kinerja merupakan titik awal terbangunnya kapasitas individu dalam memandang nilai-nilai hakiki yang harus menjadi pijakan dalam setiap mengkaji dan memilih sesuatu.

Kepedulian juga merupakan sikap terbaik yang harus terefleksikan dalam setiap aktifitas, berkeinginan kuat untuk didemonstrasikan, menghargai setiap ada tindakan yang baik yang mencerminkan nilai-nilai hakiki karakter, serta tetap memiliki komitment yang kuat untuk selalu memelihara dan mengembangkan nilai-nilai karakter yang baik. Begitu pula dengan tindakan nyata untuk selalu melaksanakan dan mempraktekkan nilai-nilai hakiki karakter sehingga terjadi penguatan secara terus-menerusyang pada akhirnya menjadi kebiasaan dan polapola prilaku yang baik.

c) Sekolah menggunakan pendekatan komprehensif, sengaja, dan proaktif untuk pengembangan karakter

Membangun karakter yang baik perlu menggunakan pendekatan proaktif dan terencana dalam mengakomodasi semua tingkatan kelas dalam suatu satuan pendidikan. Dikatakan pendekatan proaktif karena dilakukan secara intensif tanpa harus menunggu ada masalah yang timbul, tetapi langsung bertindak, baik dilakukan untuk memberi penguatan terhadap terbentuknya nilai-nilai hakiki karakter maupun untuk mencegah timbulnya penyimpangan dari karakter-karakter yang baik sebagai akibat dari berbagaipengaruh lingkungan. Dikatakan terencana karena pembangunan karakter harus didesain dalam upaya menciptakan kondisi yang baik dalam lingkungan sekolah bahkan dalam lingkungan keluargaa dan masyarakat.

d) Sekolah menciptakan masyarakat peduli karakter

Menciptakan kondisi sekolah yang peduli terhadap terhadap terbentuknya pribadi-pribadi peserta didik yang bertanggungjawab, tekun, jujur, adil sesuai dengan nilai-nilai hakiki karakter seperti telah disinggung sebelumnya merupakan kepedulian guru, kepala sekolah dan seluruh staf yang ada. Sekolah ibaratnya sebagai suatu mikrokosmos terhadap bangunan kepedulian, di mana prioritas utamanya adalah hadirnya kepedulian pendidik terhadap peserta didik, kepala sekolah kepada stafnya, peserta didik yang satu dengan yang lainnya, termasuk 
dalam membangun langkah-langkah pencegahan terhadap timbulnya tindakan kasar dan anarki yang membawa dampak negatif bagi berkembangnya budaya yang mencerminkan nilai-nilai hakiki pendidikan karakter.

e) Sekolah memberikan kesempatan kepada peserta didik untuk melakukan tindakan moral

Memberikan kesempatan yang seluas-luasnya untuk bertindak secara etis. Dalam domain intelektual, peserta didik merupakan pembelajar konstruktivis, di mana peserta didik belajar melalui tindakan nyata. Tentu saja sekolah harus menyediakan sarana dan prasarana untuk menyediakan kesempatan yang seluasluasnya sehingga aspek-aspek kemampuan kognitif, emosional dan behavioral, yang terjewantahkan dalam aktivitas peserta didik sehari-hari.

f) Sekolah menawarkan kurikulum akademik yang berarti dan menantang yang menghargai semua peserta didik mengembangkan karakter, dan membantu mereka untuk mencapai keberhasilan

Mengingat keberadaan peserta didik dalam sekolah berasal dari latarbelakang, kemampuan dan keterampilan, bakat dan minat, gaya dan kebutuhan belajar yang berbeda-beda, program akademik seperti halnya kurikulum dan kegiatan pembelajaran harus didesain untuk memenuhi individu-individu peserta didik. Oleh karena itu, sekolah seharusnya berperan dalam mengembangkan program akademik sekolah yang memberikan tantangan yang berarti dan sesuai kepada seluruh peserta didik. Selain itu, sekolah juga mengidentifikasi, memahami dan mengakomodasi berbagai perbedaan bakat dan minat, budaya dan kebutuhan belajar peserta didik. Sekolah juga harus berperan aktif dalam mengembangkan kinerja peserta didik dan mendukung pertumbuhan kapasitas intelektual, kemampuan akademik dan kapasitas untuk mengatur diri pribadi peserta didik dan budaya kerjasama.

g) Sekolah mengembangkan motivasi diri peserta didik

Motivasi diri peserta didik harus menjadi prioritas dalam mengembangkan pendidikan karakter karena filosofi karakter itu sendiri adalah melakukan sesuatu yangbaik dan pekerja yang baik sekalipun tidak seorang pun yang melihatnya. Untuk membangkitkan motivasi peserta didik, sekolah seharusnya merayakan keberhasilan peserta didik di dalam melakukan sesuatu yang mencerminkan nilainilai hakiki dari karakter dan memberikan penghargaan yang bernilai dari pada harus memberikan hadiah dalam bentuk materi.

Hal tersebut dilakukan sebagai apresiasi terhadap prestasi, hak-hak, dan kebutuhan orang lain dengan memberikan penghargaan yang bernilai tinggi dapat membangkitkan semangat dan motivasi yang luar biasa bagi peserta didik ketimbang menanamkan ketakutan terhadap hukuman atau pengharapan terhadap pemberian hadiah.

h) Staf sekolah adalah masyarakat belajar etika yang membagi tanggungjawab untuk melaksanakan pendidikan karakter dan memasukkan nilai-nilai inti yang mengarahkan peserta didik

Sekolah sebagai komunitas belajar etika harus memprakarsai terbangunnya kerjasama yang apik utamanya bagi seluruh staf seperti guru, staf administrasi, kepala sekolah, pengawas, komite sekolah, para profesional, psikolog atau 
bimbingan konseling sekolah, penggiat sosial yang membantu pengembangan sekolah,juru rawat, sekretaris, pekerja kafeteria, tenaga bantu, satpam, sopir bus sekolah, dan tenaga kebersihan terlibat secara langsung dalam mempelajari sesuatu, mendiskusikan, dan mengambil yang terkait dengan nilai-nilai hakiki karakter dan membangun rasa memiliki terhadap upaya pendidikan karakter yang terdapat di sekolah.

i) Sekolah mengembangkan kepemimpinan bersama dan dukungan yang besar terhadap permulaan atau perbaikan pendidikan karakter

Sekolah yang terlibat dalam pelaksanaan pendidikan karakter secara efektif memiliki pemimpin atau kepala sekolah yang memiliki visi yang jelas dan membagi kepemimpinannya dengan semua stakeholder. Artinya, kepala sekolah membangun visi bersama dan berpikir sistem, serta membagi tanggungjawab dan kewenangan dengan semua komponen yang terlibat dalam pendidikan karakter. Banyak kepala sekolah khususnya di Indonesia yang cenderung merancang visi pribadi yang hanya diketahui oleh wakil kepala sekolah dan tidak disosialisasikan kepada staf, guru, peserta didik, apalagi para orang tua dan berbagai komponen lain. Sekolah yang menerapkan pendidikan karakter seharusnya meninggalkan sistem kepemimpinan otokritik dan menganut sistem kepemimpinan demokratis.

j) Sekolah melibatkan anggota keluarga dan masyarakat sebagai parner dalam upaya pembangunan karakter; dan,

k) Sekolah secara teratur menilai dan mengukur budaya dan iklim, fungsi staf sebagai pendidik karakter serta sejauhmana peserta didik mampu memanifestasikan karakter yang baik dalam pergaulan sehari-hari.

Efektifitas suatu program pendidikan karakter tergantung dari sistem evaluasi yang secara terus-menerus dilakukan. Evaluasi dapat menggunakan pendekatan kualitatif dan kuantitatif dengan berbagai bentuk, seperti skor tes akademik, fokus pada kelompok, atau dengan survei tergantung dari variabel atau komponen yang dikur. Kirkpartrick, menganjurkan penggunaan empat level evaluasi seperti reaksi, belajar (pemahaman dan penguasaan), prilaku dan hasil belajar. ${ }^{32}$

\section{METODOLOGI PENELITIAN}

Penelitian ini merupakan penelitian kualitatif deskriptif. Pendekatan yang digunakan dalam penelitian ini adalah pendekatan multi disipliner (berkaitan dengan berbagai disiplin ilmu pengetahuan), yaitu: pendekatan yuridis normatif, pedagogis, psikologis dan sosiologis. Penelitian ini menggunakan dua sumber data, yaitu: 1) Data Primer, yaitu diperoleh melalui pengumpulan data dengan mengadakan wawancara secara langsung (direct interview) kepada pihak-pihak yang dianggap dapat memberikan pernyataan yang valid untuk melengkapi data yang diperoleh seperti manajemen sekolah, sebagai pengambil kebijakan dan penanggungjawab sekolah yaitu a). Guru Pendidikan Agama Islam, sebagai pelaku langsung dalam prose pembelajaran, b). Peserta didik, dalam hal ini adalah siswa, sebagai objek pengintegrasian nilai-nilai pendidikan agama islam dalam pendidikan karakter pada kegiatan rohani islam, dan c). Pengurus organisasi Remaja Pencinta Mesjid (RPM), sebagai ujung tombak pelaksanaan kegiatan-kegiatan Rohani Islam di SMK Negeri 4 Makassar. 2). Data Sekunder, yaitu data yang berupa catatan atau dokumen-dokumen yang terkait dengan

\footnotetext{
${ }^{32}$ Muhammad Yaumi, Makalah Seminar Pendidikan Karakter Bangsa: Peran Guru, Teori dan Implementasi, h. 5-7.
} 
fokus penelitian yang diarsipkan oleh pihak sekolah, yakni: profil sekolah, perangkat pembelajaran Pendidikan Agama Islam, dokumen-dokumen kegiatan Rohani Islam yang pernah dilakukan, serta dokumen-dokumen relevan lainnya.

Pengumpulan data dilakukan melalui 1). Observasi (observation); 2). Wawancara mendalam (indepth interview); 3). Studi dokumentasi; dan 4). Focus Group Discussion (FGD) yang terbagi kedalam 2 (dua) sesi, yakni: 1) FGD siswa; dan, 2) FGD manajemen sekolah. Analisis data dilakukan berdasarkan model interaktif dari Miles dan Hubermann. Langkah-langkah analisis data yang dilakukan yaitu: 1). Reduksi data; 2). Penyajian data; dan 3). Verifikasi dan penarikan kesimpulan. Untuk mengecek keabsahan data dalam penelitian ini menggunakan kredibilitas. Adapun teknik yang dilakukan antara lain: 1). Pengamatan secara seksama yang dilakukan secara terus menerus; 2). Triangulasi; dan 3). Melakukan membercheck.

\section{HASIL PENELITIAN DAN PEMBAHASAN}

Pelaksanaan pendidikan karakter di SMK Negeri 4 Makassar didapatkan melalui studi dokumen dan wawancara mendalam. Peneliti melihat bahwa pendidikan karakter di SMK Negeri 4 Makassar, terdiri dari:

1) Pendidikan karakter di setiap mata pelajaran yang dilakukan oleh setiap guru sebelum memulai materi mata pelajaran dengan durasi sekitar 5 (lima) menit ${ }^{33}$.

2) Menjadikan pembentukan karakter sebagai salah satu target capaian pembelajaran yang diposisikan sebagai penopang kompetensi kerja, yakni pengetahuan dan keterampilan kerja yang menjadi kecirian dari SMK Negeri 4 Makassar sebagai sekolah kejuruan;

3) Menjadikan penilaian sikap sebagai syarat mutlak bagi siswa untuk naik kelas;

4) Membangun budaya berkarakter dalam lingkungan sekolah, yang diwujudkan melalui program 3S (Senyum, Salam dan Sapa) dan budaya lingkungan bersih; dan, ${ }^{34}$

5) Mewajibkan siswa untuk mengikuti kegiatan pramuka, yang diakui secara nasional sebagai kegiatan yang ekstrakurikuler yang bermuatan pendidikan karakter.

Temuan di atas memperlihatkan bahwa pendidikan karakter di SMK Negeri 4 Makassar sebagian besar merupakan yang bersifat umum atau diwajibkan berlaku di setiap sekolah berdasarkan pendidikan nasional. atau program yang tergolong khusus di SMK Negeri 4 Makassar hanya 3S (Senyum, Salam dan Sapa) dan budaya lingkungan bersih. Sejauh ini, atau program yang dianggap cukup berhasil adalah $3 \mathrm{~S}$ (Senyum, Salam dan Sapa) dengan penilaian capaian yang terukur. Program tersebut dianggap mampu membangun hubungan baik dan saling menghormati, baik antara siswa dengan siswa lain maupun siswa dengan guru.

Capaian tersebut merupakan bentuk pembangunan karakter yang menjadi syarat dasar dalam menjalani kehidupan dalam masyarakat dan lingkungan kerja nantinya. Sedangkan atau program lingkungan bersih dianggap belum memperlihatkan capaian yang menggembirakan, yang ditandai dengan inkonsistensi siswa dalam menjalankannya, masih bergantung pada pengawasan dari guru dan manajemen sekolah. Dengan kata lain, belum sampai pada tahap kesadaran, atau dorongannya masih bersifat tekanan.

\footnotetext{
${ }^{33}$ Muttalib Wakasek Bidang Kurikulum. Wawancara pada tanggal 20 Oktober 2017.

${ }^{34}$ Abdul Azis Olly, Wakasek Bidang Kesiswaan. Wawancara pada tanggal 17 Oktober 2017.
} 
Adapun kegiatan ekstrakurikuler yang diwajibkan adalah kegiatan pramuka. Namun hal tersebut tidak termasuk khusus, karena merupakan pendidikan nasional. Namun dalam hal pelaksanaan, SMK Negeri 4 Makassar tergolong mampu melaksanakan tersebut dengan baik, yang ditandai dengan tidak adanya upaya pembangkangan atau penolakan dari siswa untuk mengikuti kegiatan tersebut. Sementara kegiatan ekstrakurikuler lain yang terkait dengan pendidikan karakter, seperti kegiatan Rohani Islam yang dilaksanakan oleh Remaja Pencinta Mushollah (RPM), belum menjadi khusus. Dorongan pada siswa untuk mengikuti kegiatankegiatan demikian masih bersifat inisiatif dari individu guru dan/atau manajemen sekolah.

Berdasarakan uraian di atas, peneliti menilai bahwa pelaksanaan dan/atau program pendidikan karakter di SMK Negeri 4 Makassar, baik pelaksanaan nasional maupun khusus SMK Negeri Makassar, cukup berhasil dalam membangun atau menanamkan nilai-nilai karakter pada siswa. Jika dikaitkan dengan upaya menangkal radikalisme, maka capaian tersebut dinilai mampu mengatasi tantangan dalam skala minimum. Namun untuk tantangan pada skala yang lebih tinggi, yang tidak bisa diabaikan kemungkinannya, tentunya diperlukan dan/atau program yang lebih maju dan secara khusus disesuaikan dengan kondisi kontekstualnya, misalnya dilihat dari cela atau potensi yang ada, wacana yang berkembang, model infiltrasinya dan lain-lain.

Penilaian tersebut sejalan dengan pandangan dari beberapa guru dan manajemen sekolah yang menjadi informan dalam penelitian ini, yang menyatakan bahwa diperlukan khusus untuk menangkal bahaya radikalisme, serta model atau ciri khusus pendidikan karakter di SMK Negeri 4 Makassar. "Mestinya ada, sekolah ini harus punya model atau ciri ${ }^{\circ 5}$, sebagai penegas untuk penilaian tersebut. Mengacu pada hasil penelitian yang diuraikan pada bagian sebelumnya, penyelenggaraan pendidikan karakter di SMK Negeri 4 Makassar dinilai berhasil pada skala minimum.

Hal tersebut dinilai dari kondisi sekolah yang cenderung kondusif, tidak nampak eksistensi wacana radikalisme, serta sikap dan perilaku baik yang ditunjukkan siswa. Namun realitas tersebut belum begitu teruji dalam menghadapi situasi yang lebih riskan atau lebih berbahaya. Misalnya, pada situasi dimana eksistensi wacana radikalisme sedang meningkat eskalasinya di masyarakat secara luas. Ataupun pada situasi dimana upaya-upaya dari pihak luar sekolah dalam menyebarkan paham tersebut lebih agresif atau intens dengan mencoba memanfaatkan berbagai peluang yang terbuka ${ }^{36}$.

Sehingga penyelenggaraan pendidikan karakter di SMK Negeri 4 Makassar belum bisa dinilai berhasil pada skala yang lebih tinggi, apalagi pada skala maksimum. Dengan kata lain bahwa kondisi siswa di SMK Negeri 4 Makassar masih tergolong riskan dalam menghadapi bahaya radikalisme. Sebagai catatan, bahwa potensi berkembangnya paham tersebut di kalangan siswa SMK Negeri Makassar diyakini ada, keterangan tersebut menjadi penegas mengenai potensi berkembangnya radikalisme di kalangan siswa SMK Negeri 4 Makassar.

Potensi muncul dan berkembangnya radikalisme mesti terus mendapatkan perhatian. Perlu diperhatikan bahwa lingkungan sekolah adalah satu ruang kehidupan yang dinamis dan adaptif terhadap berbagai bentuk perubahan. Intoleransi, misalnya,

\footnotetext{
${ }^{35}$ Wawancara Abdul Azis Oll, Wakasek Bidang Kesiswaan pada tanggal 17 Oktober 2017.

${ }^{36}$ Wawancara Alimuddin Sunusi (AS): Guru Pendidikan Agama Islam, paling senior wawancara pada tanggal 18 Oktober 2017.
} 
dalam keadaan yang paling kondusif sekalipun, potensi berkembangnya tetap ada, karena perubahan niscaya akan selalu terjadi pada setiap ruang dan waktu. Perubahan tersebut mencakup perubahan ke arah positif ataupun ke arah negatif. Salah satu faktor utama terjadinya perubahan adalah eksistensi konflik, baik konflik pada eskalasi yang paling tinggi maupun pada eskalasi yang paling rendah, bahkan konflik yang tidak terlihat atau terdeteksi sekalipun (konflik laten).

Mencermati capaian keberhasilan penyelenggaraan pendidikan karakter di SMK Negeri 4 Makassar, yang diulas pada bagian sebelumnya. Ditarik kesimpulan bahwa secara tekstual nilai-nilai bisa ditransformasikan. Hal tersebut mengacu pada tolak ukur normatif tentang capaian pembelajaran, dimana siswa mampu meraih kelulusan ujian mata pelajaran. Namun secara kontekstual tolak ukurnya belum nampak begitu nyata. Bahkan dalam hal kedalaman pemahaman pun belum ada indikator yang tepat dan akurat, yang didorong untuk dijadikan tolak ukur. Apalagi ketika berbicara mengenai keseluruhan dari 18 (delapanbelas) nilai-nilai karakter yang ada. Praktis hanya situasi kondusif sekolah yang menjadi tolak ukurnya. Namun peneliti menilai bahwa penilaian tersebut belum berkedudukan kuat, mengingat situasi kondusif sekolah dipengaruhi oleh banyak faktor, misalnya eksistensi aturan sekolah, kesiswaan dan lain-lain.

Perhatian utama peneliti adalah terkait dengan faktor yang mendorong penegakan nilai-nilai karakter. Tentunya penegakan yang ideal adalah penegakan yang didorong oleh kesadaran sebagai faktor utama, sedangkan kedudukan aturan adalah sebagai penguat atau penopang. Apabila aturan berkedudukan sebagai faktor utama, maka capaian keberhasilannya hanya memenuhi skala minimum. Penegakan demikian masih dominan dipengaruhi oleh tekanan atau doktrinitas, belum didorong secara dominan oleh faktor kesadaran.

Mencermati realitas di SMK Negeri 4 Makassar, peneliti menilai bahwa kondisinya masih dominan dipengaruhi oleh eksistensi aturan, baik aturan tertulis maupun tidak tertulis yang ditekankan oleh guru dan manajemen sekolah. Adapun faktor kesadaran yang didorong oleh kedalaman pemahaman akan nilai-nilai karakter belum mampu menempati posisi dominan. Sehingga peneliti berpendapat bahwa penegakan nilai-nilai karakter di SMK Negeri 4 Makassar, utamanya pada upaya membendung masuk dan berkembangnya radikalisme, masih tergolong rapuh atau riskan. Tentunya, diperlukan pengembangan ke arah yang lebih komprehensif.

Penyelenggaraan pendidikan karakter di SMK Negeri 4 Makassar secara umum telah mampu menerapkan beberapa prinsip di atas. Namun secara keseluruhan, beberapa prinsip belum bisa diterapkan. Adanya beberapa prinsip yang belum diterapkan tentunya mempengaruhi capaian keberhasilan penyelenggaraan pendidikan karakter di SMK Negeri 4 Makassar, sebagaimana dengan yang telah diulas pada bagian sebelumnya.

Radikalisme telah disepakati secara umum sebagai sesuatu yang sangat berbahaya, harus dilawan dan dibumihanguskan. Sementara, pendidikan karakter adalah pilar penting dalam membendung dan menghadapi masalah tersebut. Sehingga diperlukan gerak maju penyelenggaraan pendidikan karakter, terkhusus di SMK Negeri 4 Makassar. Gerak maju yang memastikan peningkatan capaian dari skala minimum menjadi maksimum. Gerak maju yang hanya bisa diraih apabila memenuhi seluruh substansi dan prinsip-prinsip penyelenggaraan yang telah dijelaskan, serta dengan memperhatikan faktor pendukung dan penghambat yang ada selama ini. 
Akhirnya, peneliti menegaskan bahwa pendidikan karakter harus diselenggarakan dengan tujuan menciptakan kesadaran utuh. Penanaman nilai-nilai karakter tidak cukup hanya dengan penerapan aturan-aturan ataupun melalui nasehatnasehat yang bersifat mentah. Akan tetapi harus ditanamkan melalui pendalaman pemahaman akan keluhuran dan pentingnya nilai-nilai karakter sebagi pilar utama untuk meraih kebahagiaan di kehidupan dunia dan akhirat.

Para pakar pendidikan pada umumnya sependapat tentang pentingnya upaya peningkatan pendidikan karakter pada jalur pendidikan formal. Namun demikian, ada perbedaan-perbedaan pendapat mengenai pendekatan dan model pendidikannya. Dalam hal pendekatan, sebagian pakar menyarankan penggunaan pendekatan-pendekatan pendidikan moral yang dikembangkan di negara-negara barat, seperti: pendekatan perkembangan moral kognitif, pendekatan analisis nilai dan pendekatan klarifikasi nilai. Sebagian yang lain menyarankan penggunaan pendekatan tradisional, yakni melalui penanaman nilai-nilai sosial tertentu dalam diri peserta didik.

Konfigurasi karakter dalam konteks totalitas proses psikologis dan sosialkultural tersebut dapat dikelompokkan dalam: 1) Olah hati (spiritual and emotional development); 2) Olah pikir (intellectual development); 3) Olahraga dan kinestetik (physical and kinestetic development); dan, 4) Olah rasa dan karsa (affective and creativity development) $)^{37}$.

Merujuk pada kebijakan pendidikan karakter di SMK Negeri 4 Makassar, maka capaiannya baru memenuhi aspek minimum. Tentunya, diperlukan pengembangan ke arah yang lebih komprehensif. Berdasarkan pembahasan di atas dapat ditegaskan bahwa pendidikan karakter merupakan berbagai upaya yang dirancang dan dilaksanakan secara sistematis untuk menanamkan nilai-nilai perilaku peserta didik yang berhubungan dengan Tuhan Yang Maha Esa, diri sendiri, sesama manusia, lingkungan dankebangsaan, yang terwujud dalam pikiran, sikap, perasaan, perkataan dan perbuatan, berdasarkan norma agama, hukum, tata krama, budaya dan adat istiadat.

Hingga akhirnya Kemendiknas pada tahun 2010 menyusun grand design pendidikan karakter. Secara psikologis dan sosial kultural pembentukan karakter dalam diri individu merupakan fungsi dari seluruh potensi individu manusia (kognitif, afektif, konatif dan psikomotorik) dalam konteks interaksi sosial kultural (dalam keluarga, sekolah dan masyarakat) dan berlangsung sepanjang hayat. Konfigurasi karakter dalam konteks totalitas proses psikologis dan sosial-kultural tersebut dapat dikelompokkan dalam: 1) Olah hati (spiritual and emotional development); 2) Olah pikir (intellectual development); 3) Olahraga dan kinestetik (physical and kinestetic development); dan, 4) Olah rasa dan karsa (affective and creativity development) ${ }^{38}$. Merujuk pada kebijakan pendidikan karakter di SMK Negeri 4 Makassar, maka capaiannya baru memenuhi aspek minimum. Tentunya, diperlukan pengembangan ke arah yang lebih komprehensif.

\section{PENUTUP}

${ }^{37}$ Santo Yoseph Denpasar, Pendidikan Karakter Di Pendidikan Dasar dan Menengah. (Kementerian Pendidikan Nasional Direktorat Jenderal Manajemen Pendidikan Dasar dan Menengah Direktorat Pembinaan Sekolah Mengah Pertama, 2012), h. 3.

${ }^{38}$ Santo Yoseph Denpasar, Pendidikan Karakter Di Pendidikan Dasar dan Menengah, h. 3. 
Berdasarkan paparan di atas, maka dapat disimpulkan bahwa pelaksanaan pendidikan karakter di SMK Negeri 4 Makassar, terdiri dari:

a) Pendidikan karakter di setiap mata pelajaran yang dilakukan oleh setiap guru sebelum memulai materi mata pelajaran dengan durasi sekitar 5 (lima) menit;

b) Menjadikan pembentukan karakter sebagai salah satu target capaian pembelajaran yang diposisikan sebagai penopang kompetensi kerja, yakni pengetahuan dan keterampilan kerja yang menjadi kecirian dari SMK Negeri 4 Makassar sebagai sekolah kejuruan;

c) Menjadikan penilaian sikap sebagai syarat mutlak bagi siswa untuk naik kelas;

d) Membangun budaya berkarakter dalam lingkungan sekolah, yang diwujudkan melalui program 3S (Senyum, Salam dan Sapa) dan budaya lingkungan bersih; dan,

e) Mewajibkan siswa untuk mengikuti kegiatan pramuka, yang diakui secara nasional sebagai kegiatan yang ekstrakurikuler yang bermuatan pendidikan karakter.

Temuan di atas memperlihatkan bahwa pendidikan karakter di SMK Negeri 4 Makassar sebagian besar merupakan yang bersifat umum atau diwajibkan berlaku di setiap sekolah berdasarkan pendidikan nasional. atau program yang tergolong khusus di SMK Negeri 4 Makassar hanya 3S (Senyum, Salam dan Sapa) dan budaya lingkungan bersih. Sejauh ini, atau program yang dianggap cukup berhasil adalah 3S (Senyum, Salam dan Sapa) dengan penilaian capaian yang terukur. Program tersebut dianggap mampu membangun hubungan baik dan saling menghormati, baik antara siswa dengan siswa lain maupun siswa dengan guru.

Capaian tersebut merupakan bentuk pembangunan karakter yang menjadi syarat dasar dalam menjalani kehidupan dalam masyarakat dan lingkungan kerja nantinya. Sedangkan atau program lingkungan bersih dianggap belum memperlihatkan capaian yang menggembirakan, yang ditandai dengan inkonsistensi siswa dalam menjalankannya, masih bergantung pada pengawasan dari guru dan manajemen sekolah. Dengan kata lain, belum sampai pada tahap kesadaran, atau dorongannya masih bersifat tekanan.

Adapun kegiatan ekstrakurikuler yang diwajibkan adalah kegiatan pramuka. Namun hal tersebut tidak termasuk khusus, karena merupakan pendidikan nasional. Namun dalam hal pelaksanaan, SMK Negeri 4 Makassar tergolong mampu melaksanakan tersebut dengan baik, yang ditandai dengan tidak adanya upaya pembangkangan atau penolakan dari siswa untuk mengikuti kegiatan tersebut. Sementara kegiatan ekstrakurikuler lain yang terkait dengan pendidikan karakter, seperti kegiatan Rohani Islam yang dilaksanakan oleh Remaja Pencinta Mushollah (RPM), belum menjadi khusus. Dorongan pada siswa untuk mengikuti kegiatan-kegiatan demikian masih bersifat inisiatif dari individu guru dan/atau manajemen sekolah. 


\section{DAFTAR PUSTAKA}

Anees, Bambang Q dan Adang Hambali, Pendidikan Karakter Berbasis Al-Qur'an Jakarta: Simbiosa Rekatama Media, 2010.

Azzel, Ahmad Muhaimin, Urgensi Pendidikan Karakter di Indonesia; Revitalisasi Pendidikan Karakter terhadap Keberhasilan Belajar dan Kemajuan Bangsa Yogyakarta: ar-Ruzz Media, 2011.

Cholisin, Konsolidasi Demokrasi Melalui Pengembangan Karakter Kewarganegaraan, Jurnal Civics, Vol. 1, No. 1, Juni, pp. 14-28, 2004.

Denpasar, Santo Yoseph, Pendidikan Karakter Di Pendidikan Dasar Dan Menengah. Kementerian Pendidikan Nasional Direktorat Jenderal Manajemen Pendidikan Dasar dan Menengah Direktorat Pembinaan Sekolah Mengah Pertama, 2012.

Direktorat Jenderal Pendidikan Anak Usia Dini Nonformal dan Informal. Petunjuk Teknis Pengajuan, Penyaluran dan Pengelolaan Bantuan Pendidikan Karakter Melalui Satuan Pendidikan Nonformal, Jakarta: 2013.

Fauzan, Abdul Azizl al-, Fiqh at-Ta'amul Ma'a an-Nas. Terj. Iman Firdaus dan Ahmad Solahudin, Fikih Sosial, Cet. I; Jakarta: Qisthi Press, 2007.

Husaini, Adian, Pendidikan Islam Membentuk Manusia Berkarakter dan Beradab, Cet. I; Jakarta: Cakrawala Publishing, 2010.

Kementerian Pendidikan Nasional, Panduan Pelaksanaan Pendidikan Karakter, Jakarta: 2011.

Mulyasa, E., Manajemen Pendidikan Karakter, Cet.IV; Jakarta: Bumi Aksara, 2014.

Munawar, Wahid, "Peengembangan Model Pendidikan Afeksi Berorientasi Konsiderasi untuk Membangun Karakter Siswa yang Humanis di Sekolah Menengah Kejuruan", Makalah dalam Procedings of The $4^{\text {th }}$ International Conference on Teacher Education; Join Conference UPI \& UPSI Bandung: UPI, 8-10 November 2010.

Muslich, Masnur, Pendidikan Karakter manjawab Tantangan Krisis Multidimensional Jakarta: Bumi Aksara, 2011. 
Nasirudin, Mohammad, Pendidikan Tasawuf, Semarang: Rasail Group, 2010.

Shihab, M. Quraish, Membumikan al-Qur'an' Fungsi dan Peran Wahyu dalam Kehidupan Masyarakat, Cet. XXIII; Bandung: Mizan, 2002.

Syahidin, Menelusuri Metode Pendidikan dalam al-Qur'an, Cet. I; Bandung: Alfabeta, Bandung.

Tim Kurikulum dan Pembelajaran Direktorat Pembelajaran dan Kemahapeserta didikan. Kurikulum Pendidikan Tinggi Jakarta: Direktorat Jenderal Pendidikan Tinggi Kementerian Pendidikan dan Kebudayaan, 2014.

Tim Penyusun, Pedoman Pelaksanaan pendidikan Karakter: Berdasarkan Pengalaman di Satuan Pendidikan Rintisan, Jakarta: Puskurbuk Badan Penelitian dan Pengembangan Kementerian Pendidikan Nasional, 2011.

Undang-Undang RI Nomor 20 Tahun 2003, Sistem Pendidikan Nasional, Cet. II; Jakarta: Sinar Grafika, 2012.

Yaumi, Muhammad, Makalah Seminar Pendidikan Karakter Bangsa: Peran Guru, Teori dan Implementasi (Bekasi: Yayasan Pendidikan Ar-Rahman, 2012.

Yus, Anita, "Pengembangan Karakter Melalui Hubungan Anak-Kakek-Nenek", dalam Arismantoro, Tinjauan Berbagai Aspek Character Building Tiara Wacana: Yogyakarta, 2008.

\section{Sumber Wawancara}

Muttalib Wakasek Bidang Kurikulum. Wawancara pada tanggal 20 Oktober 2017.

Abdul Azis Olly, Wakasek Bidang Kesiswaan. Wawancara pada tanggal 17 Oktober 2017.

Alimuddin Sunusi (AS): Guru Pendidikan Agama Islam, paling senior Wawancara pada tanggal 18 Oktober 2017. 